\title{
Perception of Institutional Wellbeing
}

\author{
Karina Pacheco Dohms ${ }^{1}$, Claus Dieter Stobäus ${ }^{2}$ \\ ${ }^{1}$ Postgraduate Programs in Education, Pontifical Catholic University of Rio Grande do Sul, Porto Alegre, Brazil \\ ${ }^{2}$ Postgraduate Programs in Education and in Biomedical Gerontology, Pontifical Catholic University of Rio Grande do Sul, \\ Porto Alegre, Brazil \\ Email:karina.dohms@gmail.com,stobaus@pucrs.br
}

How to cite this paper: Dohms, K. P., \& Stobäus, C. D. (2017). Perception of Institutional Wellbeing. Creative Education, 8, 1533-1570.

https://doi.org/10.4236/ce.2017.810107

Received: June 12, 2017

Accepted: August 4, 2017

Published: August 7, 2017

Copyright $\odot 2017$ by authors and Scientific Research Publishing Inc. This work is licensed under the Creative Commons Attribution International License (CC BY 4.0).

http://creativecommons.org/licenses/by/4.0/ (c) (i) Open Access

\begin{abstract}
Based on the results of Dohms Thesis, which dealt with Institutional Welfare in a Brazilian Basic Education Marist Institution, and discussions with its advisor, this article presents data of the qualitative approach, contemplating two specific objectives: 1) Verify perceptions of teachers, students, managers and employees about the Institution of which they are part; and 2) Monitor the implementation of the National Curricular Matrix in this school and the development of actions from Strategic Planning, recording the observations as field diary notes, at the same time being a researcher who is available to the develop of didactic activities, trying to describe the perception of these participants where they work and study, regarding the institutional well-being and aspects addressed in the interventions carried out, in order to reflect and contribute to their well-being. A total of 220 participants collaborated in the study, answering the questions with open answer of the Institutional Welfare Questionnaire, complemented with the Field diary notes. To analyze the data and the content analysis technique of Bardin. The theoretical framework is based on Esteve, Jesus, Dohms, Mendes and Stobäus \& Mosquera. Based on the participants' answers, they were five categories: a) Definition of Welfare, b) Aspects that generate Welfare, c) Actions for Welfare, d) Perception of relationships in the Institution, and e) Promotion of well-being. This shows that respondents and observers, in general, perceive well-being as health and relate it to belonging (spirit of family), possibility of dialogue and positive personal relationships. More positive evaluation that the person performs of itself, better is the evaluation that he/she performs of the Institution. That is, better levels of Subjective Wellbeing also reflect in better and more positive degrees of Institutional Wellbeing. We conclude that in this institution the participants cry out for appreciation and recognition, and understand that the family spirit, coexistence and interpersonal relationships promote more their wellbeing, being group spirit and teamwork primordial. They also point out aspects related to education, improvement and continuous education as necessary to promote and maintain the wellbeing in their educational institution.
\end{abstract}




\section{Keywords}

Wellbeing, Perception of Wellbeing, Institutional Wellbeing, Basic Education

\section{Introduction}

It should be noted that Dohms's Thesis (2016) has two approaches, one quantitative and one qualitative, which takes into account an Institutional Well-Being Questionnaire (QBEI) organized for this research using Likert-type response scales, which was validated, and a part with open answer questions, as well as supplemental records in Field Diary Notes. In this work, we only will delve into the qualitative data of the Thesis.

At present, we find many Basic Education Institutions, may or may not be prepared to deal with the diversity present in our educational institutions. Some of these conditions, when frustrating, can lead to a state of malaise, and there are a greater predominance of studies that investigate teacher malaise. This phenomenon, with emphasis on teacher malaise, has been increasingly studied and has received many investments in national and international research, because it has great relevance in the area of Education.

Healthy teaching must be taken into account, since it is one of the professions that have suffered most from social devaluation, accumulation of tasks, students' indiscipline, low salaries, and other factors that have been evidenced in the results of several researches. But it is also necessary to take into account the health of all those involved in the educational institution, because, in light of the concepts already mentioned, the quality of life of the teacher (his well-being) is a factor that generates effects in the chain of interpersonal relations of the institution (managers, employees and students) and direct consequences (positive or negative) in teaching and learning processes (teachers and students).

To investigate Education as a process that is concerned with the formation of the human being in its entirety, of a holistic being that is social, cognitive, emotional and spiritual, that has limits and potentials, taking into consideration that we can't separate it from its correlates in action, and preoccupied with worn-out relationships-and we have long argued about teacher malaise-helps us and reinforces the need to pay more attention.

\section{Personal and Professional Well-Being}

\subsection{Understanding the Teacher Malaise}

We know that our society is constantly evolving, and every progress brings with it many consequences, positive and/or negative, as well as solutions and/or new approaches emerge and this occurs in the various spheres of human life. With regard to malaise and well-being, taking into account that these are two approaches that have broad relations with several areas of knowledge, and specifically regarding the concern in this study, regarding the teaching profession and 
Its performance and, more generally, the interrelationships existing in educational institutions, we verify each of these terms, which suggests a range of meanings and understandings, and to arrive at these recognitions we make some distinctions, as clarifications. In this sense, we find a large number of researches that address the theme of malaise and teacher welfare.

The problem of malaise was first described by Freud, who presented several considerations on this subject in relation to civilization. At the beginning of the 20th century, when Freud (1974: p. 43) investigated the malaise of civilization, he indicated three sources of human suffering: "the superior power of nature, the fragility of our own bodies, and the inadequacy of Rules that seek to adjust the mutual relationships of human beings in the family, the State and Society". The factors pointed out by Freud, still in the 1930s, would now be associated with other factors that generate malaise.

Esteve (1999: p. 25) would add physical, emotional and cognitive symptoms, and considers that teachers suffer from malaise because they are exposed to increasing tensions due to the diverse fragmentations of teaching and, consequently, increase their responsibilities and demands, and that the term teacher malaise has been used to "describe the permanent negative effects that affect the teacher's personality as a result of the psychological and social conditions in which teaching is practiced".

Researches such as Esteve (1999, 2004), Jesus (2004, 2007), and ours (Mosquera \& Stobäus, 2006a, 2008; Dohms, 2011; Mendes, 2011) reveal that one of the greatest cause of malaise is the feeling of disagreement and teachers' dissatisfaction with the real solution of problems when teaching, which points to a contradiction with the ideal imagined by the teachers in relation to what they wish to accomplish and what they can and can accomplish.

Esteve (1999), a scholar with relevant research on this subject, considers that the first cause that distracts teachers from their profession is the absence of reflections on the meaning of the profession.

This problematic finds support from the recent contributions of Positive Psychology, which has been directing its studies more to the identification and understanding of human qualities and virtues, as well as to helping people to lead happier and more successful lives.

All these concepts and ideas highlight the need to provide healthy and good relations between managers, employees, teachers and students, minimizing malaise that afflicts not only teachers. Therefore, it is fundamental to prioritize education focused on human development as a preponderant factor, since we have been led to live apart, distanced from one another and unlearn to live in "common-unity", but we need to improve and rescue these relationships, forgotten of the human, to make the educational process more harmonic and healthy for those who are involved in it.

In Jesus' (2001: p. 125) understanding, teacher malaise "is a phenomenon produced by the present society since it is intertwined with the social changes that have occurred in the last decades, and continue to happen, with implica- 
tions mainly on the behavior of the Students".

The transformations in the role of the teacher and the traditional agents of socialization resulted from these accelerated changes in the social context, as well as needs-for example, preparation to handle information and communication technologies. But it seems that many teachers were not prepared to Deal with so many demands, which in a way has been causing innumerable situations of malaise.

Esteve (2004: p. 24) points out that in reflecting on their work, many teachers, as well as doctors and other professionals, cannot understand and find it difficult to perceive what has happened to them personally and professionally. This author recalls that in the introduction of a book by Dilthey, Ortega y Gasset warns that many people are unable to become aware of the historical epochs they have lived, of those facts that allow us to understand the problems of the present as Elements of a historical process "in which the possibility of understanding the present problems depends on our capacity to reconstruct the process that generated them, searching in the past for the roots from which they come".

This historical awareness is of the utmost importance, for much of what we see today within educational institutions is only a small part and repercussion of what we experience in our society, which has also undergone changes over the years and needs to be alert and prepared for Dealing with the new, with diversity, with the challenges of accelerated and inevitable progress.

Mosquera, Stobäus, \& Santos (2007) add that the problems that distress the teaching profession are linked to its own origin, to the historical development and to the social valorization of this profession, and the most intriguing is the uninterrupted Problematic, also in international contexts, and how socially the teaching has been worn out by the teachers' largely justified dissatisfaction, discontent on the part of the students, the poor quality of teaching and the mistrust of social use.

Mandra (1980) points out that both the teaching function has changed in the face of the pressure of changes in the social contexts in which it occupies its profession, and the expectations, support and judgment of these social contexts on teachers have changed.

Dohms (2011), in his research carried out in a private school in Porto Alegre, in Brazil, found the main sources of pressure suffered by teachers in his qualitative analysis: relationships and meetings with the parents of the students, lack of resources, daily confrontations in the classroom, verbal and physical aggression on the part of the students, lack of consensus on disciplinary matters, teaching in unmotivated classes and/or those who do not value teaching and want things done, take work home and end up interfering with family life, lack of promotion perspective, low remuneration in relation to workload, work at mealtimes or breaks, administrative tasks, having to evaluate students, decreasing respect and appreciation of society towards the teaching profession, insecurity within Bosses, poor communication between the staff of the institution, the tension in the relationships within the school and of the students with special educational needs. 
These teachers who participated in his research also indicated factors that soften these "pressures": good relations with their students, support from their professional colleagues, support from their union, clarity about their role in school, duration School holidays, unified curriculum, involvement with pastoral issues, feeling that their training is appropriate, using the bell at school and the neighborhood where the school is located. Thus it is possible to observe that teachers identify more sources of pressure than of factors and strategies to ameliorate them.

Many of the social problems are delegated and understood by society itself, and by much of the political system, as being the responsibility of Education, as if educational institutions, at their different levels, could alone account for such adversities and problematizations. Delegating to Education such a responsibility would also require greater investments, qualifications, infrastructures and, above all, recognition, because what we see are institutions with environments, professionals and processes of teaching and learning lagged, needing to adapt, with the few resources they have, in relation to the demand that exists outside of their educational environments.

According to Esteve (1999: p. 144), "teacher malaise is a social disease produced by the lack of support of society for teachers, both in terms of teaching objectives and material rewards and in the recognition of the status attributed to them". Linked to these effects, reflecting on teacher malaise, Esteve (2004), believes that what permeates this problem is that the capacity of change of educational systems is smaller than that of the social environment, a consequence of the accelerated world evolution.

Milstein, Golaszewski, \& Duquete (1984) comment that in these social contexts of teaching, when we are in a stable context, most of us teachers can face it, but when it becomes slightly even the healthiest teacher faces difficulties to cope with stress. The authors report the stable situations, which in a way become comfortable, as the changes that occur are so subtle that small adjustments can account for the educational contexts, and when these changes occur abruptly, people see themselves In the face of a stressful situation, which may in some cases become extreme, and often cannot cope with such situations because they are caught by surprise.

Rescuing these writings, Esteve (2004: p. 158) argues that "education continues to be the same commitment, difficult and balanced, with values that give quality to human life". He points out that educators from time to time need to affirm the challenge of analyzing the current context in which are inserted, as well as the educational trends, to then define among the values in force, those that will be reported and those that will be criticized, and adds that "there is no law or ministerial rule that can avoid the conflicts of our time".

That is, we need to be constantly updating ourselves to take account of and manage to follow the countless progresses of our society, and even with all this problematization and demands that cover the teaching profession, which needs to account for a true accumulation of functions, we must look beyond, seeking 
subsidies for better conditions and motivation to practice teaching, and consequently, making teaching and learning processes more qualified and satisfactory.

\subsection{Subsidies for Teacher Well-Being}

Within this perspective and concerned with the health of the teachers, the studies addressing the theme of teacher well-being emerge.

Jesus (2004) draws attention to the fact that, even though it is important to investigate teacher malaise and with a view to finding solutions to it, we risk inducing teachers themselves to consider this as "normal" this malaise, accentuating the most negative aspects of the profession, making it difficult to perceive the most positive aspects of this professional activity, which also exist.

The concept of well-being, according to Jesus (2007), is related to the motivation and the realization of the teacher, due to the set of skills (resilience) and strategies (coping) that this develops, in order to face professional demands and difficulties, surpassing them and enhancing their own functioning.

Linked to this concept is Positive Psychology which, according to Snyder \& López (2009), is directed to the identification and understanding of human qualities and virtues, and to the aid, in the sense that people have happier and more productive lives.

These two linked concepts constitute strong subsidies that move toward teacher health. Finding ways to deal with the situations of failure, stress, and other difficulties that teachers face in the day-to-day work of the profession is essential, but a look aimed at the awakening and resignification of the motivation, achievement, qualities and virtues of these professionals Assists in the promotion and maintenance of healthy and satisfied teachers.

Teaching well-being, for Jesus (2001), is connected to the positive attitudes of teachers that reverberate in their students, colleagues and even in relation to themselves, seeking to take advantage of their personal and relational qualities, and the valuing of positive aspects And the small daily successes it can achieve.

Kelchtermans (2009: p. 73), in his studies, identified five components characteristic of teacher self-understanding, which may be distinct but are interrelated and articulate with one another, and which are also linked to well-being, and uses the term "self-understanding", since it refers to a person's understanding of his Self at a given moment (product), and to the fact that this product results from a continuous process of giving meaning to oneself To their impact on the Self, "self-understanding only reveals itself at the time of "narration' (or explicit self-reflection and 'self-narration')", and (pp. 74-75) describes:

- Self-image, a descriptive component of how teachers typify themselves,

- Self-esteem, an evaluation component of teachers appreciation of their professional performance,

- Perception for the task of the teacher, of what constitutes his professional program, tasks and duties so that he can fulfill his role (normative component);

- Professional motivation, as a notion of the reasons or paths that led them to 
become teachers, as well as to stay or give up this profession (volitional component); and

- Future perspective, which reveals expectations about their future in the teaching profession (time element).

According to Esteve (2004), the number of teachers who analyze and accept the social changes of the reality in which they work is growing, considering them unavoidable for their profession, contributing to the elaboration of new improvement strategies, demonstrating them against the capacity requirements of adaptation. The author further cautions that one of the major current problems of educational institutions is that they still train teachers as if they were to work in the old educational system.

Education is a primordial element in the life of human beings, and cannot be seen or understood as mere "skill training" to perform a particular function and/or profession. We banalize the term formation, in the sense that it is perceived today only by the aspect of making people fit to practice a profession, and thereby reduce its real meaning, its historicity, conceptual and semantic (term derived from the German "Bildung"). Understanding this concept is the first step toward attitude and action changes.

Welfare has been highlighted as a fundamental element in understanding people's health. According to the Organización Mundial de la Salud (OMS, 2012), well-being is a component of mental health, which comprises a large part of activities, directly or indirectly, linked to the mental well-being present in its definition of health as "a state of complete physical, mental and social well-being and not merely the absence of disease or disease".

According to Hué García (2008) the sense of well-being comes from the balance between possibilities and desires, and between the capacities and needs of individuals. This author cites Hernández (2002), which indicates that well-being is the result of the interaction of the inherited characteristics and the learning of each person, being a deep feeling in his personality that is built during childhood and that are related to the style of Educate of their parents.

Being well-connected with personal learning, the importance of the family that is responsible for the transmission of the first learning and the creation of habits, preferably, healthier of their children, is emphasized, which in the future will also contribute to the understanding and sensation of their welfare. If we learn from the examples, the first ones we observe are those of our own family, whether they involve feeding or practicing physical activities, overcoming difficulties and motivation in the face of challenges, or even dedication to tasks and fulfillment of aspirations.

Well-being is also directly related to motivation, for which we highlight the theory of self-determination that according to authors Deci \& Ryan (2000), would be the motivation of the subjects intermediated by the satisfaction of innate psychological nutrients, essential for the continuous growth, integrity And psychological well-being. For Ryan \& Deci (2002) this mediation would involve three needs: basic psychological needs for autonomy, with the ability to regulate 
their own actions; Competence, as an ability to be effective in interacting with the involvement; and, relationship, as an aptitude to seek out and develop interpersonal connections and relationships.

This concept comes from Positive Psychology, as already mentioned, with the definition of Subjective or Psychological Welfare, which, according to Bisquerra (2010), is perceived as we are experiencing positive emotions. For the author, there are some factors for subjective well-being, such as family and social relations, love and sexual relations, professional satisfaction and free time activities. The author also alludes to factors that relate directly to well-being such as health, socioeconomic and environmental characteristics, personal characteristics, humor, laughter and vital satisfaction or satisfaction with life as a whole, all linked to the quality of life.

These relationships in turn allude to the individual component and the more subjective characteristics of the person. Subjectivity is the result of personal development, intrapersonal, and is built from the sum of lifelong learning, also contributing to the formation of identity. These relationships also occur outside the family environment, at school, in relationships with other families in the circle of friendship, and later, in adult life, at work.

Waichman (2002) states that man's work is that which produces objects by making him the slave of his production, this deepens the difference between what is produced and what he can not possess, but this difference is not only economic, but, Especially human, since the product cannot be considered a source of development for his spiritual and aesthetic life, nor even enriches his humanity.

In this perspective, Birman (2006: p. 183) argues that the possession of goods defines the status of the subject and "to have, to fill the void, is a sign that confers security to the individual, because it makes him believe that he has some Power by the status it can display", considering that excess is part of contemporary malaise.

Most of the time, the man ends up alienating himself to work in search of what he wants to have, in favor of his own recognition as a free being, that is, "the man feels free when he is not working and when he does he considers himself lost their freedom”, says Waichman (2002: p. 23).

This is another dilemma of modernity, the obligation to fill in gaps, and time as well, since people feel guilty for not working and consider, in some cases, that they are doing nothing "productive", a Instead they should be focused on the use and profit of a moment that is their right, if not still necessary for their quality of life.

Portal (2008) points out that, often in the attempt of (re-)significations, we are faced with what we are and what constitutes us, so that we begin to realize that the "having" is worth so little when there is no "Being" that supports it.

Mosquera \& Stobäus (2010: p. 68) consider that:

The de-spiritualisation of work, through its emptying in the sense of meaning, is what gives the human being his embarrassment and impotence. It is rather 
painful and alienating to work just to survive, but it is far worse to work just for that, without having a forward-looking perspective and a performance and understanding of the task, and a sense of direction and homing/ humanizing.

This should not mean that it is only possible to have satisfaction, interests, or even fun out of work. Work should also be a task that generates pleasure and motivation, after all it is part of human life, and there is the impossibility of separating personal life from work. We are unique beings, constituted in a wholeness. However, when feelings about work become intolerable, the anxieties generated, whether by the group or the working environment, will have repercussions in the other environments in which the person lives, coexists, interacts, and that is where the concern for Welfare issues.

Boff (1999) believes that work and care compose and stresses that the great challenge of the human being is to be able to combine them.

Codo (2006: p. 110) points out that "with meaning and meaning, the working conditions and attitudes of the worker become good predictors of each other; And if there is not, the explanatory power between them disappears".

In the face of globalization, everything has become faster, people cannot find the time to carry out their tasks, commitments and responsibilities. Brazilian labor legislation establishes that the "normal working day" is eight hours a day (40 to 44 week hours), but many professionals work far beyond this average, in addition to professionals who take work to be done at home, at which time they should dedicate themselves to family, social activities or even personal. So that many families could manage their schedules and daily activities, considering those who have one or more children, children also had to enter at this same fast pace, in which often parents without whom to leave them. The late adults, who a few years after their retirement stayed at home and often helped their children in the care of the grandchildren, are now active and active in the labor market; they are forced to keep them busy with various activities using contracting of services.

Sousa (2006: p. 34) mentions that we are in a risk factor whenever the characteristics of the person or the moment are associated with an inadequate development. This happens every time a new challenge arises and its demands transpose the subject's adaptive capacity, making his reaction to this same dysfunctional challenge.

What the author mentions is noticeable, since rapid changes often provoke and require of people an adaptation that is sometimes not prepared. Adaptations occur over time, but depending on the charges and urgency that some cause may arouse negative feelings, or as the authors define, they trigger a risky situation.

For these and other reasons that have not been addressed here (such as: human rights, current family formatting, political and economic systems, social inequality and others), we need to rescue the essence of the human being, his virtues, values, aspirations, Needs and desires, as well as valuing actions that allow one's own (re-)knowledge, so that he/she can be not only an actor but also the author of one's own life, enjoying a healthier and happier life. 


\section{Positive Psychology and Other Components towards Well-Being}

Positive Psychology emerged from the perspective of humanity's well-being, which in the 1990s, which was much more concerned with the positive aspects of human beings, suggested that human qualities should be explored in order to develop skills and competences More suitable for overcoming difficulties, for the personal and professional satisfaction of people.

Positive Psychology, according to Jesus \& Rezende (2009), emerged from Humanist Psychology based on Maslow's ideas. It was only then in the 90s, of the last century, that Martin Seligman introduced the term Positive Psychology, presenting his views on the necessity of this scientific approach.

According to Snyder \& Lopez (2009: p. 19), "the science and practice of positive psychology is directed towards identifying and understanding human qualities and virtues, as well as helping people to lead happier lives and more productive". The authors warn of the fact that Positive Psychology offers a glance on the other side that once was not attributed by Classical Psychology because it was more concerned with the pathologies, defects and sufferings. It is believed that in this positive perspective, Psychology should develop (Snyder \& Lopez, 2009: p. 22) "an inclusive approach that examines the defects and qualities of people as well as the stressors and resources that are present in the environment" to have a more satisfying life.

These ideas of Positive Psychology are applicable in our actions, since the world of ideas reflects on these applicabilities, and through the relationships of the human being with his world, the needs arise to conceptualize and acquire better levels of understanding. In this sense, Positive Psychology envisages that the future of the human being is to do better, as we are able to transform our lives, if we want, investing in the search for meaning, love, joy and spirituality for health and wellness-be.

Mosquera \& Stobäus (2011b) consider that Positive Psychology extends the focus of interest of human behavior as a whole, covering its behavior/behavior, emotions/feelings spectra, which in turn should be broadly understood as a study of the Psycho-optimal functioning, covering the point of view of individuals, groups and institutions.

Seligman \& Csikszentmihalyi (2000) cite that Positive Psychology aims to begin to catalyze a shift in focus from Psychology, which is concerned only with repairing the worst things in life, to jointly build positive qualities.

Seligman (1998) further stresses that psychology also adds to the study of qualities and virtues, not only weaknesses and injuries, since "treating" does not only mean fixing what is defective, but also cultivating what we have best.

Mosquera \& Stobäus (2011a) observe that for a long time we already know the need to interact positively with others in order to detect our own eigenvalue, which leads us throughout our lives to understand the constitution of reality as a long psycho process-education of great value and vital need.

Valuing and investing in the most positive aspects reflects directly on the development of the human being, since it will have greater chances of gains, which 
must be achieved, than losses, not only psychological, but also physical, social, cultural-philosophical losses, Also, an appeal to Positive Psychology.

Another concept from Positive Psychology is the so-called Subjective WellBeing, which Diener (1984) defined as the combination of positive affect and general satisfaction of the human being with his own life, being this a subjective evaluation in relation to his current situation in the world. The author still uses this expression as a good synonym of happiness.

Snyder \& Lopez (2009: p. 137) quote Seligman, who suggests that "from the happiness that results from the use of our psychological qualities, one can build a pleasurable and meaningful life".

In order for this self-judgment to be effective, recognition of the other(s), as well as their relationship to him/her, is indispensable. Positive relationships are essential for well-being, and this analogy is inversely proportional. Perhaps the great dilemma is the fact that we are not/were prepared to see our qualities, potentialities, and virtues.

Mosquera \& Stobäus (2012) point out that, in the constant construction of oneself, as the person recognizes himself as a singular being, he also opens perspectives to the plurality of the other profound "I's" (the meaning of the human). This plurality, together with the possibility of new perspectives, enables the person to expand in terms of human dimensions, capable of exchanging values, strengths and virtues, knowledge and ideas, abilities and attitudes.

Snyder \& Lopez (2009) report that for years asking their customers about their qualities and defects, almost without exception the answers about their defects are more immediate than about their qualities.

This requires opening new horizons, in which the human relation does not fade into massification, since these singularities and particularities of the human being pass through the quality of consciousness. Positive Psychology excels by a healthy approach, by optimism, by hope, in order to provide opportunities for people to grow together with motivation to live.

Another component related to Positive Psychology is the resilience that, for Grotberg (1995), is a result of particular characteristics combined with sociable behavior, temperament, character and intelligence.

According to Sousa (2006: p. 39), a resilient person implies the presence, search and gradual increase of his confronting skills in the face of adversity, seeking help in his own resources (biological, psychological, contextual). Resilient subjects, according to the author, have the "propensity to maintain high expectations as to the future itself, as well as the clear establishment of objectives to be attained". Highlights three extremely important concepts to be worked together with resilience:

- Competence, for example, components of cognitive content;

- Hardiness, used as a personality trait expressed by cognitive, social and physiological mechanisms that protect health and performance while still being able to withstand stress; and

- Coping, which correspond to the terms "deal with" or "coping strategies". 
Still, Sousa (2006) considers that resilience is part of a lifelong development perspective, since it takes place in a continuum of adjustments in face of the daily difficulties faced by people and their capacity to face them.

Resilience is the person's ability to adapt to storm situations with a view to the most positive aspects, that is, being able to use the fundamental aspects proposed by Positive Psychology, facing and overcoming such adversities.

Mosquera \& Stobäus (2012: p. 863) point out that Positive Psychology has close links with Health Psychology, both of which are extremely important so that there is an "understanding of everything that can lead to self-construction and the development of healthier forms of human personality".

Mosquera \& Stobäus (2011b) also understand that social support directly supports those aspects of better and more positive health, since positive social networks act directly on promoting self care and health maintenance. This social interaction partially protects people from the pathogenic effects of situations considered more stressful when used to implement levels of resilience.

Recalling that Positive Psychology is based on three main pillars (positive emotions, joy, illusion and thanksgiving), it is imperative to know and cultivate traits of personality that help us to be better and happier. These pillars are linked to the vision of Health Psychology and envision a range of aspects that constitute the human being as well as their relationships in the world. A positive and healthy vision of the person ascends to his own well-being.

\subsection{Idealization of Institutional Well-Being}

Also, positive institutions (society, family, company, etc.) that support, promote and value positive emotions and personal aspects of people complement and assist in the positive construction of human beings in search of their dignity, for respect, Health and happiness is everyone's right.

Snyder \& Lopez (2009), in relation to employees and students, declare that the results desired for them, even though they are well formulated, generally as productivity and learning respectively, should be inserted by adding more positive results.

Morin (2009: p. 99) points to the impasse that "one cannot reform the institution without a prior reform of the minds" that constitute it, and vice versa.

This initiative should start from management teams that, even if they are acting indirectly, are at the forefront of these processes, with a view to progress and institutional health. Individual actions are necessary for each sector, but common actions and goals also foster the sense of acceptance and belonging, and it is perfectly possible to work together within diversity.

According to the Delors (2000) Report, when human society seeks its cohesion in common projects and activities, it enriches material and spiritual bonds and brings out feelings of belonging to the community and of solidarity.

Marchesi (2008: p. 123) concludes by saying that "the sense of belonging to a group contributes to self-esteem and personal balance".

Masschelein \& Simons (2002) consider that the educative relation is consti- 
tuted in a being-with-others, moment that we find ourselves.

This self-recognition comes to fruition as we see the other and the other, their needs, abilities, feelings, difficulties, values, and we often share these aspects. We are able to meet each other, for we see ourselves in the other, being essential for this self-awareness to be possible. Being with others allows you to not only realize exchanges and to bring about a sense of belonging, but opens up different possibilities and ways of being with other people, building new knowledge, discussing, disagreeing, waking up and planning new perspectives. With this we develop empathy, sympathy and strengthen our human values by establishing relationships of affinities, respecting differences.

For Maturana (1998: p. 32) it is the love that is at the heart of human coexistence, in the "actions that constitute the other as a legitimate other in the realization of the social being that both lives in the acceptance and respect for itself as in the acceptance and Respect for the other". The author calls it the "biology of love", and it is incumbent upon it to occur in a normal process as we live in it.

Frequently, in the most diverse situations, we hear the maxim that says "who loves care", which alludes to the link between love and care. Care implies a certain prudence, attention, and dedication to something and/or someone. Education also presupposes care, and whoever educates is also a caregiver.

Cassassus (2009) affirms that these are absolutely essential for the human being to survive, since they guide behavior in relation to two basic principles of life: self-preservation and preservation of the species.

Healthy and good relationships are fundamental in the life of the human being, enabling him to have a more beneficial trajectory in a way that develops positively, recognizing, with esteem, himself and the constituents of his wholeness, as well as the others that are part of his Interactions.

In an educational institution these concepts are perfectly applicable and increasingly emerging. Care, resilience, affection, well-being, health and positive psychology are essential for people to stay motivated and united by the same ideal: a quality education, full of meaning and meaning for all those involved in the Knowledge.

With this, we highlight the definition of Institutional Well-being proposed by Dohms (2016: p. 147):

Institutional well-being, as a result of the effectiveness of the institution as a result of a harmonious, effective and affective coexistence, coming from all its collaborators in the action, and the promotion of a healthy environment in which teaching and learning processes (in the case of an educational institution) more significant, generating positive effects throughout the chain of relations that constitute the institution.

To build a healthy institutional environment, based on empathy, respect and affection, spaces and actions need to promote positive human relationships, in order to obtain more productive, meaningful and shared success results. Contude, investments should also take into account the expectations and interest of the people who will be receiving such interventions, seeking to contemplate all 
those aspects that constitute them as human beings in an integral approach. One strategy might be to initiate an approach that verifies their perceptions about a particular theme/subject/problem/situation.

\section{The Responses of Teachers, Students, Managers and Employees about Welfare}

The objective of this article is describe the perception of teachers, employees, managers and students of a Marist school in Porto Alegre, where they work and study, regarding institutional wellbeing and aspects addressed in the interventions carried out, in order to reflect And to contribute to the wellbeing of these people, two specific objectives of the qualitative part of Dohms (2016) Thesis were: 1 ) To verify the perceptions of teachers, students, managers and employees in relation to the Teaching Institution of which they are part; and 2) To monitor the implementation of the National Curricular Matrix and the development of actions from Strategic Planning, recording the observations in Field Diary Nortes, being, as a researcher, available to the college to develop didactic activities. The research was approved at ESchool of Humanities and at Brasil Research Platform n. CAAE 168448.13.5.0000.5336.

This institution, in the year 2014, when the research was carried out, had about 831 students (of these, 193 High School students), 44 teachers, 50 employees and 10 professionals who held the position of educational management. A total of 220 people ( 36 teachers, 7 managers, 6 staff and 171 students), all invited to participate participated ay the research, responded a Consent Form and the instruments. Answered the five open-ended questions: 1) For you, what does Wellness mean? 2) Describe up to five aspects Which generate Wellness in your Institution of Teaching; 3) What suggestions would you give to maintain a Welfare atmosphere in your Institution of Education? 4) How you feel about the people who are part of your Institution Do you feel open to doing placements and dialogue with people? Do you feel welcomed in this environment? Make a brief report justifying your perception; and 5) What actions/initiatives/formations do you believe would be necessary and beneficial to keep the well-being established in their Institution of Education?, constituted from the qualitative corpus of this study, the Institutional Well-Being Questionnaire (QBEI).

Also, Field Diary Notes were used for complementary records, unstructured or free observation (teachers, managers and employees: in meetings, management group, recreation, teachers' room and after the interventions, students: during recess and some visits during classes), in an individual way (only the researcher), in which she verify the perceptions of teachers, managers, employees and students in relation to the Teaching Institution of which they are part.

For the analysis of the qualitative data, we used the Content Analysis Technique proposed by Bardin (2010), with categorization, and with the complementary data of the Field Diary in its initial stage of floating reading. This technique was used by means of categorization in a pre-analysis, through cut-offs of the registration units (words, phrases and significant units) related to the objec- 
tives of this study and using categories defined a priori (from the questions themselves), being: 1) Definition of Welfare; 2) Aspects that generate Welfare; 3) Actions for Welfare; 4) Perception of relationships in the Institution; and 5) Promotion of Welfare.

\section{Results and Discussion}

Next, the data will be presented based on the analysis of the five questions with open QBEI response, contemplating the specific objective of: Verifying the perceptions of teachers, students, managers and employees in relation to the Teaching Institution of which they are part.

In order to elucidate each category, some responses from the research participants were transcribed with similar discourses. In order to do so, the identification of the answers mentioned was performed as follows: the initial letters designate the person's function in the educational institution, followed by the subject identification number (questionnaire number), and after the hyphen is indicated by a digit (where the emphasis is on the same subject and question). For example, "G18-2" would be a manager identified as number 18 (eighteen), second part of his writing. Therefore, we use "G" for manager, "Do" for teacher, "F" for employee and "Di" for student.

For the discussion of the results presented here, it was decided to base it theoretically on the Marist referential of education, since it deals with the opinions and reflections of the people in relation to the institution to which belong, in this case, a Marist college of City of Porto Alegre. However, we emphasize that this option of theoretical reference used to discuss the results presented here does not limit the reflections and discussions, but contributes to these in different educational contexts because it is a theoretical approach based on human values and that deal with themes related to Education with ownership and actuality, making possible a universal adaptation.

The first category, called Definition of Welfare, refers to the understanding that the research participants have in relation to the term Welfare. From the QBEI's first open-ended question, they were invited to report what they thought was the expression Well-being. From the analyzed answers, eight subcategories of the definition of the term were defined, as presented in Table 1, sorted in decreasing order according to the frequency of responses of the research participants. That is, the first subcategory refers to the answers with more frequency, the second with less frequency than the first, and so on, being the last subcategory presented in the Table referring to the lower frequency of responses.

These positions in the speeches come to the meeting of the authors who deepen in the topics covered, as for example: G167, Do185, F173, and Di150.

For Bisquerra (2010), as we are experiencing positive emotions, let us also perceive well-being. The author also points out that this construct has been studied in several areas, and should not cause strangeness if we find other denominations, such as subjective well-being, psychological well-being, quality of life, satisfaction with life, happiness and others, to designate the term welfare. 
Table 1. Subcategories of definitions of welfare.

\begin{tabular}{|c|c|}
\hline Subcategories & Discourse of the people researched \\
\hline Feeling good & $\begin{array}{l}\text { F: } 173 \text { Feeling good in the environment in which you live and work. } \\
\text { Di3: For me, it means being right with myself and with others, cherishing inner peace without hurting others. }\end{array}$ \\
\hline Intimacy & $\begin{array}{l}\text { Do181: Balance in the dimensions of our existence. } \\
\text { Do185: Being physically and emotionally well. } \\
\text { Di146: Well-being for me means a peace or relief with the outer and inner world. }\end{array}$ \\
\hline Quality of life & $\begin{array}{l}\text { Do184: Being physically and mentally well. } \\
\text { Di27: Well-being means being fit (healthy) to fight for what you want/believe. } \\
\text { Di150: Being in good health. }\end{array}$ \\
\hline (co)experience & $\begin{array}{l}\text { G167: It feels like being with you, with the people with whom we live daily and trusting in a superior being (who does not } \\
\text { abandon us). } \\
\text { G168: Being with whom I love. } \\
\text { Di25: Be satisfied with the people around me and myself. }\end{array}$ \\
\hline Realization & $\begin{array}{l}\text { Do189: Feeling fulfilled as a person within choices made and assumed throughout life. Organization and management of time } \\
\text { in order to create a healthy dynamic of life. }\end{array}$ \\
\hline Reception & Di24: The reception of the people who are part of the educational institution. \\
\hline $\begin{array}{l}\text { Psychological } \\
\text { state }\end{array}$ & Do180: Well-being is a psychological state. However, it can receive permanent external stimulus from society and other people. \\
\hline Productivity & F175: Productivity (take time positively). \\
\hline
\end{tabular}

Source: Dohms (2016).

According to Hué García (2008: p. 156), "the sense of well-being is the result of a balance between possibilities and desires, between capacities and needs".

We can see from the participants' writing that the expression "well-being" refers to positive feelings about their own life, being evident in the three subcategories with the highest frequency of occurrence in their responses: 1) Feeling good, which refers $t$ feel good about yourself and others, to feel calm and secure in your life and at work; 2) Integrality, in the sense of maintaining the balance between the constitutive dimensions of Being (physical, mental, emotional, spiritual), feeling of inner peace, inner and outer balance, self-knowledge; and 3) Quality of life, making mention of a favorable state of health (physically and mentally), practicing physical activity and having healthy habits.

It is important to point out that, in order to establish relations, reflections and considerations, we have noticed that there are some elements that deal with Marist Education (Cotta, 1996; União Marista do Brasil, 2010; Maristas, 2015a, 2015b); citations about well-being, but these do not talk about the subject, only mention, being that most of the time is related to the students.

There are some documents that cite health and welcome, the latter in a sense of well-being-it is relevant to think and verify whether educational institutions take into account the health of the people who are part of it, and whether there are evidences in their documents and/or Records. However, there is evidence of this concern, especially in the letters and writings of Saint Marcellin Champagnat (founder of the Marist Institute), which, for the most part, began by counting the health of the Brothers who were closest and of those who had news, as, it expressed the wish that the recipient(s) of the letter would be well. Concerns 
about cleanliness, accommodations (good beds for the Marists, for example), clothes, food, and also perpetuating the problems were also addressed in the letters addressed to mayors, parish priests, and people they were dealing with prayers.

Champagnat once recommended an Education in a broader (integral) sense, as Cotta (1996: p. 81) emphasizes, "of every man and of every man". The author recalls that he was incisive with the brethren of the congregation regarding the education of the body, referring to health, strength and vigor, and hygiene. An education through sports and physical exercises: (p. 82) "to carry out good work of education is also to deal with the physical development of the child".

Says Cotta (1996: p. 82) that "the educator, during the time when the students are entrusted to him, must preserve them from all evil influence, to the physical and to the spiritual; Leads them to achieve for their members the strength and energy of which they are capable".

There are also two cross-cutting characteristics of the professions of students, teachers, managers and collaborators in the Marist School of Education (União Marista do Brasil, 2010: p. 73-74), in the item called the organization and dynamics of Marist schools: "educate with affection, with a willingness to help the subjects of the school to overcome themselves continuously, thus favoring the construction of self-esteem, self-image, self-confidence and protagonism"; and "to contribute to the guarantee and promotion of human rights and to social transformation, by participating in sociopolitical and cultural processes that promote a full life and the construction of a just and solidary society". Also, in the duties assigned to the office of manager, we emphasize that of "managing the organizational climate of the school, solving conflicts and guaranteeing an institutional environment marked by a sense of belonging, co-responsibility and family spirit'.

Therefore, realizing and understanding that well-being is of fundamental importance for people's lives, as well as recognizing the various factors related to this construct, which also needs to be preserved and stimulated, helps them to lead a full and happy life. This unleashes good feelings and sensations, when coupled to a chain of relationships and interactions, as is the case of educational institutions, where these relationships and interactions are constant and lasting, and in fact fulfill their commitment to quality Education. Being a partner in these processes, especially with regard to institutional well-being, is fundamental to preserve not only good feelings, but also to strengthen group spirit, favoring teamwork, making the environment lighter, welcoming and healthy.

The second category, named Aspects that generate Welfare, refers to the notes made by the participants of the research, as those that they consider and/or recognize as being generators of well-being in their Teaching Institution, which they are part of Table 2, that shows, in its subcategories, eight aspects present in the answers analyzed, as generators of well-being in this Marist college.

The subcategory called Family Spirit appeared in the writing of the vast majority of research participants as the most relevant to their well-being. These, 
Table 2. Subcategories of the aspects that generate well-being.

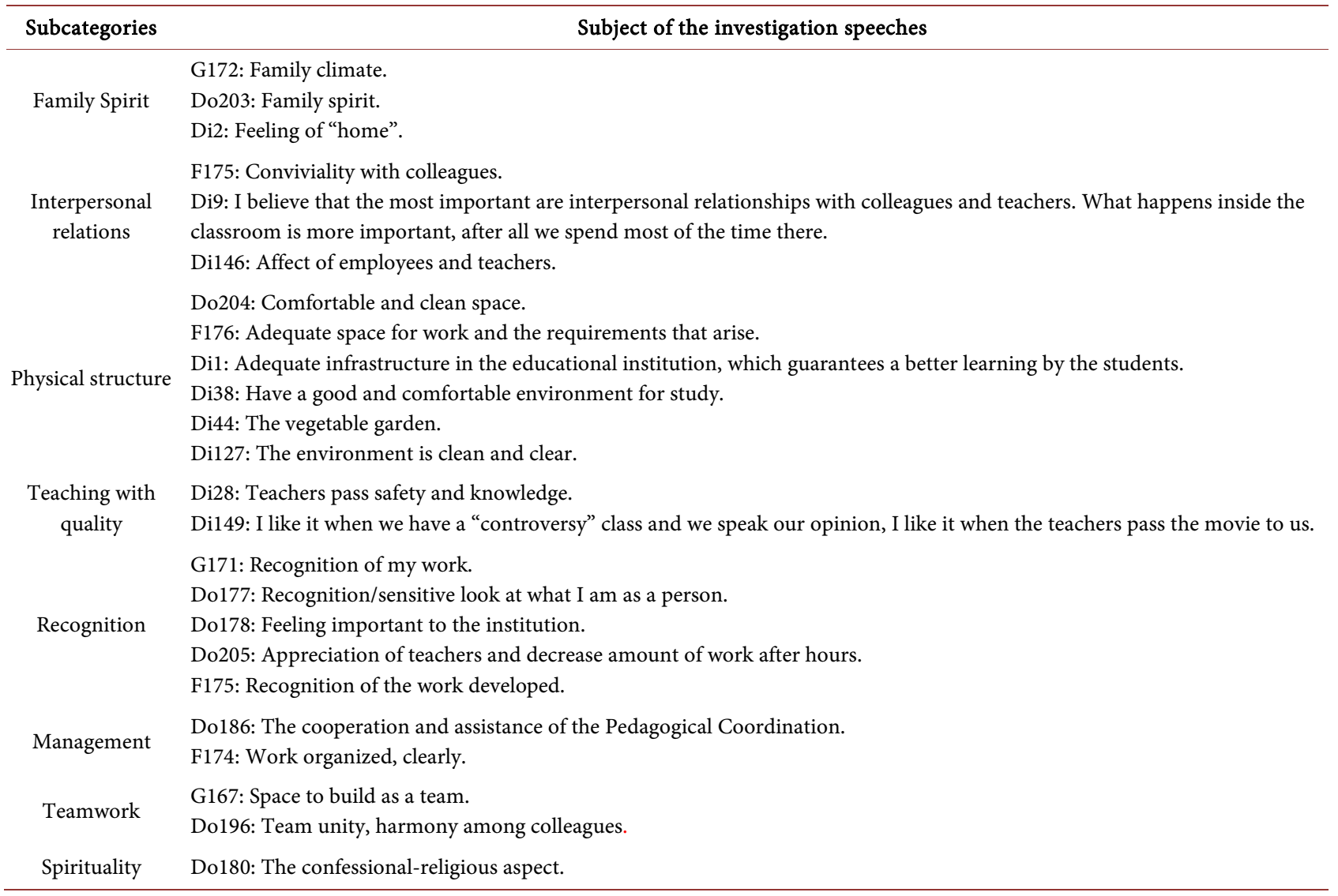

consider their institution of education as their "second home", or as one of the students pointed out: Feeling of "home" (Di2). Added to this element, Interpersonal Relations, which is intimately related to the Family Spirit, appears in the sequence since, healthy and good relationships arise from this feeling of home, of family spirit. Thus, one of the employees emphasizes "Comfort with colleagues" (F175) as positive and generative of well-being, implying that these interpersonal relationships are extremely important since they enable the people involved to put their skills into practice to relate to their own emotions and feelings, determining their way of acting, and can contribute to a positive work environment and study.

For this discussion, we will recall Marist principles, which are part of the approach defined as Marist Pedagogy. An own approach, which translates into the form of concretizing the identity of the Institutional Mission, a pedagogy of love, dedication, respect and everyday practical applications (Cotta, 1996; União Marista do Brasil, 2010).

These principles are in line with the results found from the analysis carried out, especially in this category, which highlights the aspects of the Teaching Institution that generate well-being in the people who belong to it.

Marist education has its own character, which is differentiated by the Family Spirit, which alludes to the coexistence suggesting a fraternal relationship be- 
tween the educational community, in order to favor the development of people and the establishment of bonds (União Marista do Brasil, 2010).

This reinforces the ideal traced and experienced by St. Marcellin Champagnat, founder of the Marist Institute, who insisted on the importance of the school's general environment for the formation of students, stressing that, according to Cotta (1996: p. 61), "be the spirit of the family. Now, in a good family, in a well-ordered family, the feelings of respect, love and mutual trust dominate".

The family spirit for the participants designates the perception of a familiar climate within the institution, in which there is respect, space for dialogue, receptivity and welcome, unity and harmony. Interpersonal Relations, however, refers to the relations established and the approximation with the other people of the institution, as well as to the environments that promote these relationships, of healthy coexistence.

These three subcategories most frequently cited in the writing of the research participants (family spirit, interpersonal relations, and physical structure) reveal a sense of belonging to the institution. Feeling at home, with healthy relationships and an adequate physical structure, enables the quality of the processes offered and developed by the institution. A school environment with an attractive, clean and organized physical structure, makes possible the interest for the development of physical and cognitive activities, allowing people to feel at ease to relate to each other, thus effecting the family spirit.

Based on the suggestions of the study participants about how to maintain a climate of well-being in the educational institution to which they belong, the category 3) Actions for welfare, presented in Table 3.

As shown in Table 3, the participants consider, more frequently, as actions relevant to well-being, the Opening for dialogue, in which one of the suggested aspects would be "Improve internal communication" (F175), mentioning that it is necessary that There is greater clarification regarding the processes and/or guidelines of the institution, favoring even a unit of action. Another note from the participants was regarding Recognition, in the sense that there should be "Maintenance of a staff that values the institution" (Do193), this aspect was also pointed out by the students, who feel the constant changes of professionals, which hinders the formation of a cohesive and stable work team. This "maintenance" of the staff refers to the professional recognition, it would also be linked to the feeling of belonging, already treated in other categories, a professional who identifies with the Marist philosophy and who through his actions demonstrates at least some identification or affinity with it.

Mosquera \& Stobäus (2006b: p. 84) warn that "every human being needs positive valuation, the most real possible, because it is through the internalization of the experiences of valuing others for him that the learning will be made, in any order".

Recognition, cited by the participants, demonstrates a need to be recognized, whether through praise or evaluation of their actions in the institution, as well as in their responses, indicate the importance of constant evaluations, such as 
Table 3. Subcategories of welfare actions.

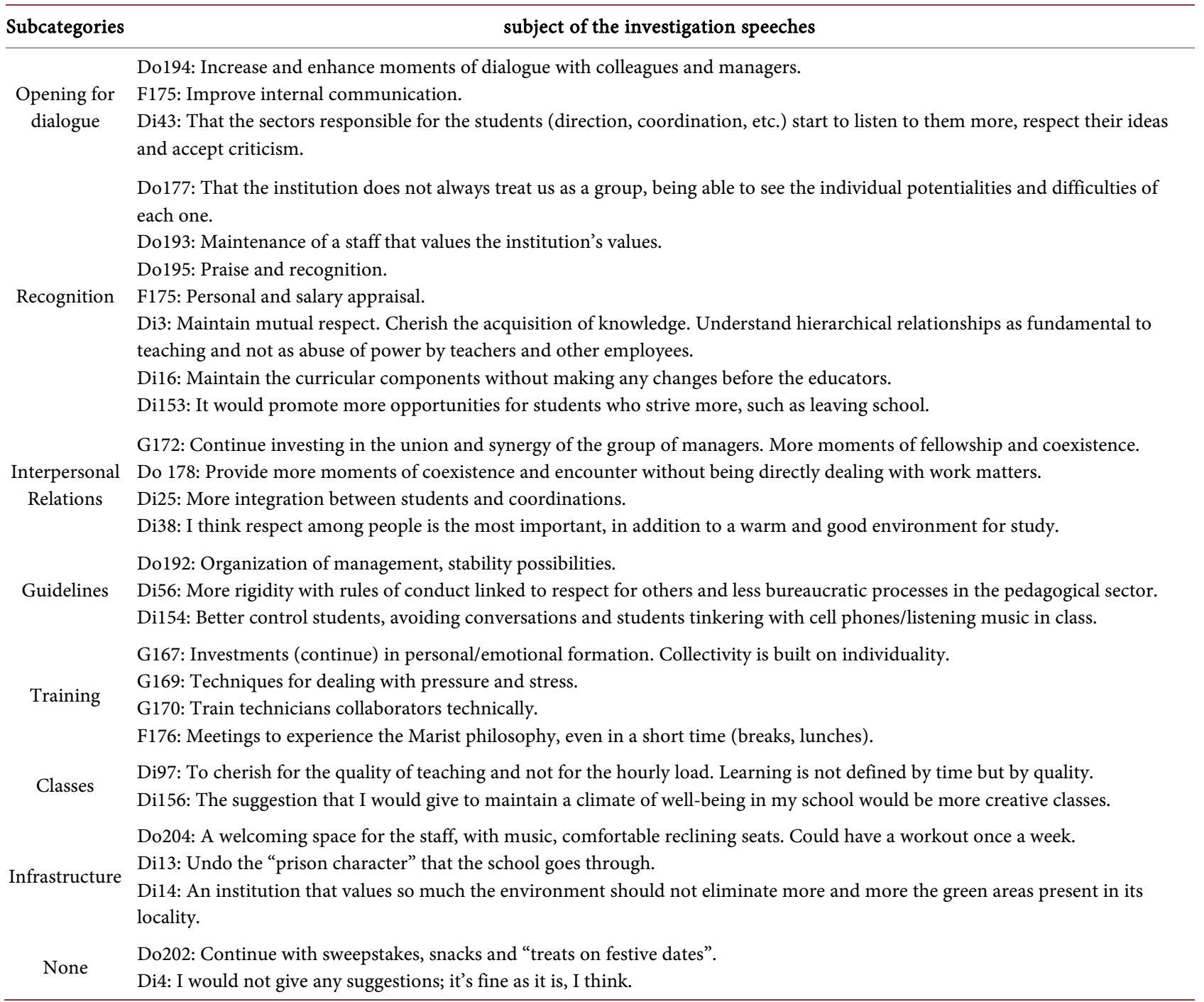

feedbacks, that should be carried out systematically, giving return and greater security in relation to the work developed.

It was also suggested to continue investing in interpersonal relationships, as expressed in the speech of one of the managers (G172). This aspect appears in the speech of many participants as relevant to maintain the well-being, nevertheless emphasize the importance of continuing this investment, which shows that they recognize this as already existing and primordial for healthy processes of the educational institution.

The Presence, another differential of Marist education, which as well as delivery, are the central elements of this pedagogy, involving the educational community in a movement of trust and sharing, in the practice of listening and dialogue, since it extrapolates the school space, requiring New postures in the face of contemporaneity, as well as an incentive and coherent action between discourse and action, being the relations based on affection (União Marista do Bra- 
sil, 2010: p. 26), and the expression space, used in the Educational Project to characterize the Marist school, is defined as "a continuum that refers to space and time in an interrelated way".

This differential, which values the practice of listening and dialogue, converges with the suggestion of the participants of the research that point out the openness to dialogue as fundamental to their well-being. Suggests to welcome and understand the speeches of those who are part of the institution in its different spheres and relationships, in which people are more accessible, more receptive and respectful, and more flexible, and in this context, the management team is closer to the employees.

The three subcategories presented here come from the majority of respondents' answers: Opening for dialogue, Recognition and interpersonal relations. These are present in the differentials of Marist Education, either explicitly or implicitly, and in turn effect the teaching and learning processes ensuring the mutual identification between people and these with the philosophy of the institution.

Named 4) Perception of relations in the Institution, this category refers to the way in which the participants of the research feel in relation to the other people who are part of their educational institution. From the participants' perception of the relationship established in the Teaching Institution, it is evident the mention of Positive and Negative aspects, in the written of the researched as shown in Table 4.

Table 4. Subcategories of the perception of relations in the institution.

\begin{tabular}{|c|c|}
\hline Subcategories & subject of the investigation speeches \\
\hline Positives & $\begin{array}{l}\text { G172: I feel happy with the new direction, which I did not feel before, in the old direction. I feel open to dialogue, respect, care, } \\
\text { recognition and appreciation. } \\
\text { Do195: I perceive full openness and clarity in the relationships between colleagues and superiors, with a truly active reception and } \\
\text { initiative of welcome and well-being. } \\
\text { Do202: The constant monitoring of the notes, positive return of the difficulties overcome. Suggestions and ideas to improve } \\
\text { practice. } \\
\text { F174: Work place with pleasant colleagues and always willing to help, where the dialogue occurs in the various moments adding } \\
\text { and sharing values. } \\
\text { Di1: The feeling of welcome is very present in the school, since it tends to promote respect, education and fraternization among } \\
\text { all. }\end{array}$ \\
\hline Negatives & $\begin{array}{l}\text { Do186: It is no use to coordinate work for the union of the group if there are colleagues encouraging the disunity, manipulating } \\
\text { even the students. } \\
\text { Do179: I see a growing demand for teachers' production, as well as for the excellence of these instruments, but in contrast, there is } \\
\text { a shortage of time for these productions during school hours. Including even "rest" moments of the teacher being used as part of } \\
\text { the work schedule (e.g. correction of tests and warnings during recess). This certainly makes the school environment unhealthy. } \\
\text { Do198: Not always welcoming from colleagues, possibly due to a sense of competition in the teaching environment. } \\
\text { Do203: I feel that I live well, but I do not feel comfortable to make criticisms and/or placements, just compliments. } \\
\text { F176: Regarding people, I feel that we still have a feeling of "not belonging", not feel belonging to the group. } \\
\text { Di44: In the old days the school was a more familiar environment, which made relations easier and today I feel little recognized as } \\
\text { a student, because people do not strive to maintain a good relationship. The dialogue is done, but it is not interpreted by the } \\
\text { superiors and by many teachers. } \\
\text { Di64: Less class time, we do not have much time for ourselves. } \\
\text { Di152: Sometimes I feel like I do not make too much of being with some colleagues, maybe because I lack respect among some. It } \\
\text { "prevents" me from knowing them any more. }\end{array}$ \\
\hline
\end{tabular}


Some people emphasize as Positive aspects the respect, welcome, family environment, dialogue, teachers, good interpersonal relations, openness for professional activity, these being considered notes present in the day-to-day of the institution of education, as for example: G172 and Di1.

The participants' reports show a sense of acceptance and security towards the people who are part of the institution, since they point out that there is a clarity in the processes and a constant aid, which denotes healthy relationships.

However, a significant group of people described aspects that they considered Negative, according to some of the reports: Do198, Do203, F176 and Di44.

We can see, from the participants' writing, that the negative aspects are made some identical positions as the positive ones, but obviously, in a contrary character. Here, aspects related to lack of reception, respect and dialogue between people appear; Individualism and impersonality; the disorganization, which is often tied to a lack of clarity in the actions and events that occur in the institution; also the lack of professionalism and relationship problems.

"Simplicity permeates actions based on dialogue and open, fraternal and coherent relations with Marist values, in order to strengthen solidarity, confidence and, consequently, closeness between the entire educational community" (União Marista do Brasil, 2010: p. 44). Together with humility and modesty, these virtues that are represented by three violets, characterize the Marist spirit.

This Marist principle-simplicity-reminds us of the speeches of the research participants, who perceive weaknesses in the relationships established within the educational institution to which they belong, since this principle reinforces the importance, precisely of dialogue and relationships in order to generate The rapprochement between people. Even though some notes seem to contradict each other, since they sometimes appear as positive and sometimes as negative, they indicate that something is not totally in agreement, aligned, in harmony, since the majority indicated negative aspects. These elements, precisely because they are present in these two spheres, must be considered in order to make these relations more positive, in order to benefit the processes and the interactions among all, since they need a closer look, they need clarification in order to have the consent of all.

According to Asensio (2006: p. 156), the relations in the work are:

Closely connected with the emotional components of the expectations in the actions that seek goals, within the work in the culture, are the cognitive processes of search of causes (attribution), which are activated in situations that are not very transparent in themselves, especially in those where success or failure leads to personal involvement, mobilizes self-esteem, emotional strata and motivations.

Conscious that an institution is formed by different people, each as a single and multiple being, in the sense of having their own characteristics of personality and their individualities, as well as their experiences, aspirations and interactions with others in the world, it is necessary, And even emerging, to be attentive to the different looks and positions to form a healthy organizational culture, 
with a view to institutional well-being.

The Education Project of Marist Brazil itself considers that the subjects of education and of the school bring with them "their histories, conceptions, ideas, values and meanings constructed in broad and different sociocultural universes", a subject "in relation to the world and with God, capable of constituting themselves and of constituting the world, subjects of the make-think of education" (União Marista do Brasil, 2010: p. 55-56), recognizing the plurality of identities.

Perhaps this research group had its own impressions and expectations regarding the institution, but over time it encountered some difficulties and needs in the face of the institution's guidelines, processes and directives. Even if these documents do exist, whether in the form of guides, manuals, guidelines, etc., it is essential and timely that they are effectively used, consulted, mentioned, and even clarified.

As explicit in the reports, it is also a complaint both of teachers and of students the time devoted to school tasks. Teachers consider spending a lot of time in the preparation, correction, and preparation of materials; And students believe that they spend many hours at school, with a large amount of study time (two-shift classes, six periods in the morning shift) and at home solving school tasks (themes, assignments, etc.).

Soratto \& Pinto (1999) point to an increase in the mental load, since the greater the number of hours worked, the greater the suffering of the workers.

This quote from the authors, although referring to the educators, can be adapted for all the public studied here. Any human being who requires and devotes long hours to cognitive activities (i.e. study, reading, planning, etc.) leads to exhaustion that can lead to even physical and psychological symptoms such as headaches and stress.

Another need is to demonstrate high levels of performance and/or efficacy, to which Jesus (2007) warns us, where there is no guarantee of remaining in work, considering that there is a high level of unemployment, and many potential employers take advantage of this situation, leads many people to the need to hide behind a "mask of effectiveness" proving to be quite competent and effective, otherwise their jobs will be jeopardized.

Students experience this pressure when they need to take large-scale assessment tests, such as selective tests.

For Menezes and Gazzotti (2006: p. 372-373):

No matter how much you deny, a teacher is a teacher twenty-four hours a day. He is in constant state of attention and vigilance; can never fully relax. So much so that no sign with misspellings goes unnoticed, no slip of agreement ceases to "hurt" in your ears. Every newspaper and television news is always received for educational purposes. The teacher simply cannot "hang up" completely. Even in the holidays, he is quite capable of enjoying a Brazilian literature book or adding little shells to the beach for collage work with his students. It is always plugged in and preferably 220 watts. If he does not demonstrate this agitation physically, try to penetrate his thought that you will see it. 
This state of attention and vigilance mentioned earlier, and that generates some agitation, may be related to the demands of the labor market, which requires efficacy, competence, proactivity and innovation, as well as other issues, making people increasingly concerned about giving Account of so many demands and collections. With these imposed needs, they generate a state of competition among the teachers, which was mentioned by the participants as another negative point of the relations in the institution.

Both teachers, students and staff cite that they do not feel they belong to the group, even if they report having good relations with the people of the institution, they do not really have this sense of belonging.

If we look closely, we will see that these negative notes, made by the research participants, can be triggering sources of each other, that is, a particular situation or event/attitude may be giving rise to other situations that generate negative feelings towards them.

In this category, it is worth mentioning that the management team that responded to open QBEI questions highlighted only positive aspects of the relations in the Institution, citing the dialogue and healthy organizational climate.

Category 5), called Wellness Promotion, brings the notes made by the research participants in order to promote well-being in their Teaching Institution. Table 5 presents the subcategories from the actions that they deem necessary and beneficial to promote and/or maintain the well-being of those who belong to the educational institution.

According to Table 5 data, it is possible to observe that most of the outstanding answers are teachers and students, who represent almost the entire group, who made notes to promote Welfare in the Institution. Noting that of the group of teachers, only one expressed satisfaction regarding the actions taken in the welfare of the Institution, not making other comments, the others answered pointing out proposals.

The three most cited subcategories in the writing of the research participants relate, respectively, to aspects related to chores, improvement/activities and appreciation/recognition.

The Chores are closely linked to the processes performed by the people in the institution and their point of view in relation to them, being emphasized in the participants' speech the need for a return on these tasks. Thus, they express: "feedbacks" (G172, Do179-1, F176-1 and Di68).

Love for work is also a principle of Marist Pedagogy, and is based on the example of St. Marcellin Champagnat, who with his tenacity and dedication undertook many projects and considered dedication to work an essential element of human formation. "This commitment favors the strengthening of the character, morals and fundamental values of life, and must be cultivated throughout the educational community" (União Marista do Brasil, 2010: p. 45).

According to Ashford \& Cummings (1983: p. 372), feedback would be the "information available in the working context of individuals, indicating the degree to which they are achieving the goals". 
Table 5. Subcategorias da promoção do bem-estar.

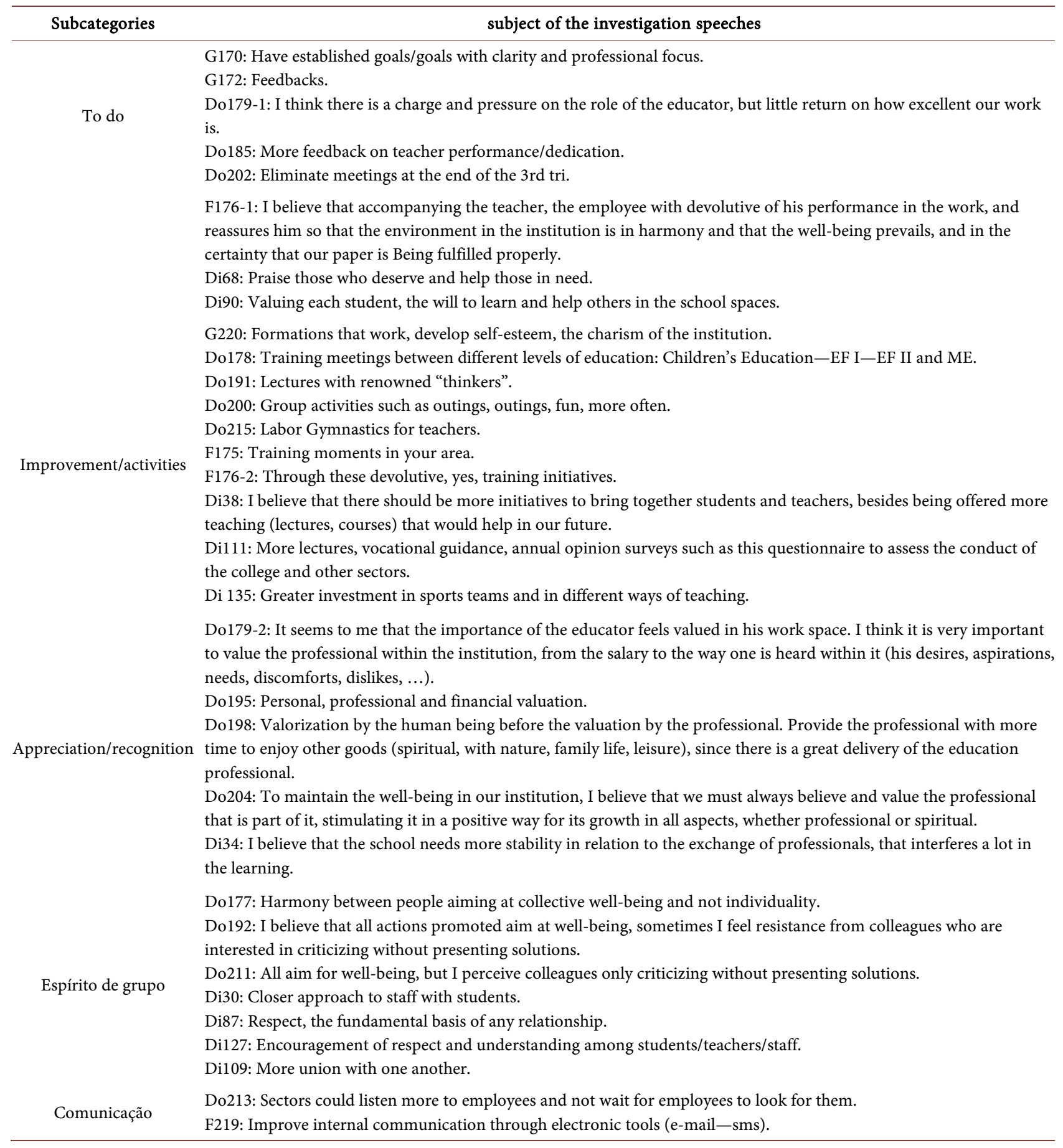

Fonte: Dohms (2016).

Since feedback is an indispensable condition in relation to objectives and performance, and from what the research participants have signaled in relation to their dedication to the teaching institution, there is a clear need for more frequent feedback and feedback on performance. These moments of return may make the work climate lighter, as they will be aware of how the institution, represented by its managers, perceives the work developed and what they really 
expect from these tasks that each function develops, so that the institution's processes are more positive and prosperous. All people consider that they are dedicated and committed to the fullest by the educational institution (they have love for their work) and, in some way, yearn for an evaluation, a constructive point of view and/or criticism, no matter how It is expressed, manifested, demonstrated, as long as it is significant and appropriate, contributing to personal and professional growth.

In the subcategory Improvement/activities, the participants mention ethical-moral formations, by areas of activity, which promote self-esteem, which deal with the charism of the institution, vocational talks, etc. Just as they propose that there will be more moments of fraternization, work gymnastics and investment in sports teams.

For Imbernón (2010), training, whether in the form of a course or lecture (for example), centered in the school should have its strategies developed jointly by the trainers and those who will participate in such an improvement, so that they respond to the needs defined by the institution Which contribute to improving the quality of teaching and learning. It emphasizes this training as a promotion of personal, professional and institutional development, making the work a motto for the transformation of the practice, which goes beyond scientific, didactic or pedagogical updates, provides a practice based on the theory and reflection of this.

In the speeches we highlight, we see that there is a demand for professional improvement, as well as a sense of orientation and/or acquisition of new knowledge. All participants cite, as a suggestion to maintain their well-being, these moments of improvement, concerned with their doing in the institution and with their personal growth. Reflecting on their lives and having the possibility of improvement and differentiated experiences contribute a lot to the people who work or study in the institution, feel even more belonging and also valued.

From the Field Diary Notes records, we verified that, during the school year in which the research was carried out, there were "Formation/training Meetings" (so named and planned in the school calendar) with specialized professionals dealing with themes such as Human Rights and Intelligence Emotional; Pedagogical meetings prioritizing the formative character and dealing with themes and/or demands that emerged from the school routine and teaching and learning processes, as well as meetings that also promoted the collective study of the new Curricular Matrixes that were being implemented, some of them counting on the support and guidance of the team of the Education Committee of the Marist Network. To the students were offered training meetings, which took place twice a week during the school year, given by the School Ministry team (in the intervals or in the inverse shift the classes) and sports (some also offered by the network of schools), counting often with the support of the Student Guild.

However, despite the fact that these training meetings were offered, none of the participants made mention of this initiative of the institution, not even highlighting the importance of continuing these actions offered, but only report the 
need for training. It seems redundant, once these moments have been promoted, but it suggests that the participants envisage formations that meet their own demands while belonging to an educational institution. Once again we stress the importance of these actions being collectively built, that the group's goals, strategies and/or needs are taken into account, aligning the improvement offered with the expectations of those who will be participating.

Already the category Valorization/recognition, brings some demands, as in the writing that follow: "In order to maintain well-being in our institution, I believe that we must always believe and value the professional that is part of it, stimulating it in a positive way for its growth in all aspects, whether professional or spiritual. Reinforce your potential as a human being at all times, rescuing your experiences and experiences so that you can share with the group" (Do204).

Esteve (1999) comments that there is a lack of social support for teachers, and that the salary issue is the one that weighs most heavily in the decision to leave the profession.

For Soratto \& Olivier-Heckler (1999: p. 95):

But it is not just wages that the work and the worker live. The latter includes among the desirable requirements in a company the possibilities of career progression, which means the social and financial recognition of the effort of this worker in the pursuit of professional growth.

Among the reflections expressed by the group of teachers (from the complementary Field Diary Notes records), the need for salary valorization was explicit. These justify that they dedicate much to the educational institution, working beyond the contracted workload, since many planning and organizations are realized beyond this period that are in the college. In fact, the teaching profession is one of the most undervalued, and this has repercussions on low adherence to undergraduate degree programs. Even when people feel inclined or inclined to follow a teaching area, then they choose to pursue other professions or are encouraged (the family has a great influence) to pursue other course options. The teachers, in their writings, claim, in a certain way, a professional recognition with salaries commensurate with the work and effort expended the activities developed by them.

Students often point out that there should not be too many teacher exchanges, since they should be valued and kept in the institution for longer. The students' manifestations are in line with the appreciation and recognition desired by the teachers of the study, since they also feel the changes that occur annually and feel, sometimes, hurt by such changes.

In addition, it also appears in the teachers' writing the suggestion for personal valuation before the professional, because they feel very pressured against the results and demands of the institution, and these charges appear, in their opinion, to exceed the limits of the institution And always seem to be chasing after results and materials to be filled, rather than worrying about and focusing on the main reasons for the institution: the teaching and learning processes. 
In general, the research participants mention that one should maintain the family climate, respect and understanding; and to promote well-being requires more dialogue (knowing how to listen, improving internal communication), enabling people to get to know each other better, to have more time for themselves, to avoid teacher exchanges, to invest in courses/lectures and in sports.

In the records made in the Field Diary Notes, a range of activities were carried out at the initiative of the research institution participating in the research, with a view to valuing professionals. Among them, aimed at teachers, managers and employees, monthly draws of cinema and theater tickets, book tickets, this time being held at the time of the interval and always added a well diversified and filling snack. Also, on the last working day of each month a celebration is organized for the birthdays of the month (at the time of the break), at which time some birthday party favors are delivered, everyone sings the traditional "Congratulations" and shares a snack offered by institution.

The data presented here give rise to many strategies and actions that will collaborate to make possible an environment and people with high levels of institutional well-being, in the following section, we try to bring some reflections from the interventions made.

\section{Intervention for Welfare}

As a researcher, being at the disposal of the college and attentive to her processes, accompanying in this institution the implementation of the "National Curricular Matrixes" and the actions from her Strategic Planning, were made available two face-to-face moments: 1) to develop didactic activities dealing with research topics, Institutional well-being, fulfilling the specific objective; 2) to follow the implementation of the National Curricular Matrices and the development of actions from Strategic Planning, recording the observations collected in the Field Diary Notes, being, as researcher, available to the college to develop didactic activities.

For these activities, we already had partial research data (under analysis), the participation of the researcher in the Group of People Management (in which there were already reflections on the well-being of the institution's people) and some observations of the follow-ups of the Pedagogical Meetings focused on the implementation of curricular matrices, which made it possible to verify some of the demands that emanated from the people who constituted the teaching institution, in all its instances, helping to outline activities in order to obtain more productive and meaningful results, and Attempt to contribute to healthier interpersonal and institutional environment aspects.

Three teaching activities were proposed, dealing with themes related to Institutional Well-being, and these moments were made available, and previously scheduled, according to the demands of the school calendar, with the participation of teachers, employees and managers of this, present in the Moments of these activities. The activities were proposed according to the objectives of the research, considering the subjects, the theoretical references and partial data of 
research addressing the proposed theme. To do so, these moments were elaborated in a way that contemplated the theme of Welfare, adapting and improving the ideas for the school level.

For Mosquera (1978), some practical possibilities can help people to obtain and maintain their well-being as the suggestions pointed out by Biehler: to develop self-awareness; Seek new possibilities for continuing education; Assess dissatisfaction; Reevaluate workload; Dedicate time for rest and leisure; Talk with friends and family; Stimulate discussion in groups with other teachers; Seek a pleasurable physical activity; Avoid discharging frustrations in students; Seek professional help when all the above aid is not sufficient.

The activities carried out had the objective of promoting awareness and dialogues about well-being in order to address themes that would help the participants in their lives, not only in the professional aspect, but in all those that constitute the human being; Clarifying the concepts about these worked themes, perceiving and understanding their problematizations; Providing moments of reflection, connecting theory and practice, and when possible and/or necessary giving space for discussions that would contribute to the institution and its agents.

As previously mentioned, these activities occurred in three moments, the first one by sending two articles for reading, related to the central theme "Wellness and teaching health" (Esteve, 2005) and "Formation ('Bildung'): between the sacred and the profane" (Sattler, 2011). The second occurred in September with a group of teachers, staff and managers, with duration of 1 (one) hour, dealing with the theme of Welfare broadly proposing reflections related to the themes of Good and Evil, Being and teacher welfare and beyond teaching, meaning and meaning of work, welfare constructs, human beings and their relationships, institutional well-being, actions and possible strategies for the promotion of health and well-being.

Rescuing the records of the Field Diary Notes (dc), recalling that they are complementary, in the first activity, which consisted of sending the texts, there were positive manifestations of some participants of the research, who when they found the researcher commented on the reading and others expressed themselves Responding to the email sent and thanking the contributions provided by reading the articles.

In the second didactic activity it was possible to observe that the participants were attentive and reflective to the subjects discussed, with few comments from the participants during the presentation of the themes, highlighting only the speech of one of the participants who emphasized the importance of Positive Psychology-Have a background in psychology and know and master the subject-for a more positive and optimistic "look" of the human being for his life and how these aspects can contribute to make it healthier and faith.

In the second didactic activity it was possible to observe that the participants were attentive and reflective to the subjects discussed, with few comments from the participants during the presentation of the themes, highlighting only the 
speech of one of the participants who emphasized the importance of Positive Psychology - Have a background in psychology and know and master the subject - for a more positive and optimistic "look" of the human being for his life and how these aspects can contribute to make him healthier and happier.

According to Snyder \& Lopez (2009: p. 19) both the science and practice of Positive Psychology point to the identification and understanding of the qualities and virtues of the human being, helping people to have happier and more productive lives.

From this perspective, at the end there were some reports from the participants, who showed a certain concern at that moment, in the sense of perceiving and giving due to the fast pace that their lives took and, most of the time, if ever, the Difficulty in being able to stop and make such reflections, think about their lives, their work, their needs and desires. After this intervention some people reported to the researcher that if it were not for that moment intended the proposed reflections, they would certainly not have been able to think and rethink their lives, considering the constitutive dimensions of the being and the people around them.

For Timm (apud Santos \& Carreño, 2010), teaching is a profession of help to the other, who possesses in alterity its raison d'être. Remember that caring for the other does not mean neglecting yourself, because the education of the other always passes through the education of self, so the care of the other will also require a care of oneself.

And the third didactic activity, held in December, with the participation of about 18 teachers and staff, with duration of two hours, addressed the theme of welfare, taking into account a deepening of the concept of well-being; The human being in its wholeness, its constitutive dimensions and the individual investments for each of them; Spirituality: meaning and meaning of life; Affectivity, emotions and feelings; Positive Psychology; Self-image, Self-esteem and Self-realization; and Health Education.

In this last proposed moment, the participants interacted more effectively, showing an interest in the topics discussed, as well as bringing questions and sharing their experiences. The speech of a participant who throughout the discussions realized the importance of respecting and being able to choose to contemplate a beautiful sunny day, taking advantage of cycling or even taking a "chimarrão" (brazilian gauchos tee) instead of organizing materials to be used in the future Their classes, that is, time management and the organization allied to health and well-being. "Give yourself time", as participants realize that much of their time is spent and dedicated to work, even when they are already at home with their families.

Dohms (2011), in a research carried out with teachers, showed that these devote an average of 6.22 hours a week to homework (correction of school tasks, preparation of classes, preparation of tests, planning of meetings, elaboration Posters and research materials, etc.), at which time they should be concerned about their family life. 
These didactic activities sought to sensitize the participants to the proposed themes, using different resources: texts, videos, songs, problem situations and group dynamics. The interventions and the notes made regarding these were used in order to contribute to the Institution from its agents and to complement the research data.

Rogers (1997) states that the maximum that an individual can do for another is to create certain conditions in order to make learning possible, since the person can't be forced.

Thinking about health, continuous improvement together with self-formation, reflective formation and working together, we propose these activities in order that all those who constitute the teaching institution, could see themselves as unique beings and also as protagonists of this institution that live and live together for common goals. That in the diversity that constitutes this Institution, there are also affinities and different points of view and pluralities, which make the Institution what it is and represents for each one and for the community to which it is inserted.

Throughout the monitoring of the implementation of the National Curricular Matrices, it was possible to observe the group of teachers and managers who were very committed and dedicated to being able to put into practice what this new guiding document presented as challenges, linked to the knowledge and practices already developed. Moments were made available for planning by area of knowledge (Languages, Codes and their Technologies, Mathematics, Human Sciences, and Natural Sciences).

According to a manager of the institution, as recorded in Field Diary Notes, "the implementation of the Curricular Matrix is a milestone, our college is one of those in this 'pilot project' and needs these investments of study, exchanges and reflections between peers, and we are doing what we can to legitimize these spaces". (G1dc).

At the Pedagogical Days, there were also moments of exchange between levels of education, and the support and advice of the Marist Educational Management (Marist Province). These moments were considered by the participants as "very rich", as in the lecturer's words: "in addition to allowing dialogue among colleagues, it also allowed us to see different perspectives, different understandings about the same construct, skill and competences" (Do20dc).

Jung (1972) believes that a healthy person should have three basic characteristics: sensitivity, intuition and feelings, and these should be developed throughout his life. Sensitivity, which is the attempt to grasp the subtlety of other people's feelings; intuition, would be an imaginative and creative knowledge that all human beings possess; and, the feelings, also recognized, as forms of knowledge.

These characteristics, directly or indirectly, were included in the instrument proposed by this research (QBEI) and corroborate Jung's ideas, insofar as the participants were invited to reflect and give their personal opinion, as sincerely as possible, about the to which they belong, feelings and emotions experienced, about their personal experience in relation to well-being. These points refer to a 
personal reflection about oneself and the relationships and perceptions we have of others.

\section{Conclusion}

The objective of this article was to describe the perception of teachers, employees, managers and students of a Marist school in Porto Alegre, where they work and study, regarding institutional well-being and aspects addressed in the interventions carried out, in order to reflect and contribute to the well-being of these people, based on two specific objectives of this qualitative part of the Thesis (Dohms, 2016) 1) to verify the perceptions of teachers, students, managers and employees in relation to the Teaching Institution of which they do part; and 2) to monitor the implementation of the National Curricular Matrixes and the development of actions from Strategic Planning, recording the observations in complementary Field Diary Notes, being, as a researcher, available to the college to develop didactic activities. It should be noted that they were taken care of.

Through the analysis of the open-ended questions and complemented with the observations made in the Field Diary Notes, concomitant with the interventions carried out (didactic activities), and we observed that in the five categories presented there are some similarities, that is, there are aspects that the participants of the research report that appear in more than one category, which in turn confirms the veracity of the information presented in their writings. We highlight, briefly, the notes related to valuation and recognition, mentioned in categories of numbers 3 and 5; The family spirit, coexistence and interpersonal relations that appear in categories 2, 3, 4 and 5; Group spirit, teamwork, mentioned in categories 2 and 5; And aspects related to training, improvement and training, mentioned in categories 3 and 5 .

All the participants highlight the positive characteristics of the institution, among them, the family climate, the possibility of dialogue among people, the clean and organized environment for study/work, but also highlight points to improve, among them: All those who are part of the institution, who should be healthier and based on respect; The appreciation and recognition of the work of teachers and staff and student performance; More moments of feedback and space to actually dialogue; Many of the participants mention that there is space, but that they do not feel comfortable for dialogue to exist; And the lack of feeling of belonging to the institution/have no sense of belonging.

It is also evident that some initiatives that start from the institution itself, in order to promote moments of well-being and sharing among people are not always effective. The participants' responses demonstrate a need for reflection on their work in the institution (work, study, goals, clear objectives, feedbacks, etc.), the need for training that meets the demands of those who constitute the teaching and learning institution and Recognition of these, which reinforces the importance of conducting surveys and listening to people.

The Field Diary Notes was a relevant complementary instrument during the research, allowing, from the observations, to make records that showed that the 
Institution endeavored to provide different moments for all those who constituted the school, could participate and integrate to the group (raffles, lunches and/or commemorative dinners, birthdays of the month), as well as providing continuous training (lectures, pedagogical meetings and moments directed by the Marist Educational Management), as well as moments of study and planning together. However, we also find that some actions are not recognized by the participants, suggesting that they may not actually meet the expectations and aspirations of the people who constitute the institution.

We also verified that the more positive the evaluation that the person realizes of itself, probably the better the evaluation that will realize of the Institution. That is, better levels of Subjective Well-being also reflect in better and more positive degrees of Institutional Well-being.

In order to build an institutional environment based on empathy, respect and affect, it is necessary to create spaces and actions concerned with human relations, to obtain more productive, meaningful and shared success results, which reinforces the investment in programs and interventions dealing with Theme of the welfare, of themes that aim to help people in their lives, seeking to contemplate all those aspects that constitute them as a human being in an integral approach, clarifying the concepts about the themes worked, providing moments of reflection (connecting theory and practice). And when possible, the development of strategies will come to contribute with the institution and the people are part of its.

The analyzes presented here are not exhaustive, since the reflections and notes from the results obtained during the research, per hour, respond to the objectives outlined and presented in this article, but give guidelines for future studies that can be carried out longitudinally, Perhaps with more in-depth interventions, with greater involvement of all involved, and perhaps even more active participation of the student's family. We also share the ideas of Positive Psychology so that there is more investment in the more positive aspects of the human being. Investments linked to their initial and ongoing training, effective and affective coexistence in the work/study environment, and especially with regard to health and well-being.

As we have described, there are initiatives that start from the institution itself, in order to promote moments of wellbeing and sharing among people. Nevertheless, in the participants' registers there is a need to reflect on their work in the institution (work, study, goals, clear objectives, feedbacks, etc.), the need for training that meets the demands of those who constitute the teaching institution and valuation and recognition of these.

In the five categories presented we also observed some similarities, that is, some aspects that the research participants report and that appear in more than one category, which in turn confirms the veracity of the information presented in the writings. We highlight, briefly, the notes related to valuation and recognition, mentioned in categories of numbers 3 and 5; The family spirit, coexistence and interpersonal relations that appear in categories 2, 3, 4 and 5; Group spirit, 
teamwork, mentioned in categories 2 and 5; and aspects related to education, improvement and training, mentioned in categories 3 and 5.

For further researches we can give some practical applications and considerations. First, the data obtained in the present study serve as a parameter to other investigations, whenever we emphasize that they are partial, therefore they can be generalized to this population, but with caution to other studies.

We remember that it would be very interesting to maintain contact with the same school participants, in a sense of carrying out longitudinal research, to verify these data.

We also believe that conducting continuing education with the different investigated segments, for example through courses, workshops, reading incentives and other activities, could make the school and its members better complemented.

\section{References}

Asensio, J. M., Carrasco, J. G., Cubero, L. N., \& Larrosa, J. (Org.). (2006). La vida emocional. Las emociones y la formación de la identidad humana [Emotional Life. Emotions and the Formation of Human Identity]. Madrid: Ariel.

Ashford, S., \& Cummings, L. (1983). Feedback as an Individual Resource: Personal Strategies of Creating Information. Organizational Behavior and Human Performance, 32, 370-398. https://doi.org/10.1016/0030-5073(83)90156-3

Bardin, L. (2010). Análise de Conteúdo [Content Analysis] (3rd Ed., p. 70). Lisboa: Edições.

Birman, J. (2006). Arquivos do mal-estar e da resistência [Archives of Malaise and Resistance]. Rio de Janeiro: Civilização Brasileira.

Bisquerra, R. (2010). Educación emocional y bienestar. Wolters Kluwer Educación: Madrid.

Boff, L. (1999). Saber cuidar: ética do humano-compaixão pela terra [Knowing How to Care: Ethics of the Human-Compassion for the Earth]. Petrópolis: Vozes.

Cassassus, J. (2009). Fundamentos da educação emocional [Fundamentals of Emotional Education]. Brasília: UNESCO, Liber Libro Editora.

Codo, W. (Coord.). (2006). Educação: carinho e trabalho [Education: Caring and Work]. Petrópolis: Vozes.

Cotta, G. (1996). Princípios educacionais de Marcelino Champagnat [Educational Principles of Marcellin Champagnat]. São Paulo: FTD.

Deci, E., \& Ryan, R. (2000). The "What" and "Why" of Goal Pursuits: Human Needs and the Self-Determination of Behavior. Psychological Inquiry, 11, 227-268.

https://doi.org/10.1207/S15327965PLI1104_01

Delors, J. (Org.). (2000). Educação: um tesouro a descobrir [Education: A Treasure to Discover]. São Paulo: Cortez.

Diener, E. (1984). Subjective Well-Being. Psychological Bulletin, 95, 542-575. https://doi.org/10.1037/0033-2909.95.3.542

Dohms, K. P. (2011). Mal/bem-estar docente, auto-imagem e auto-estima e autorealização em uma escola tradicional de Porto Alegre [Teaching Malaise/Well-Being, Self-Image and Self-Esteem and Self-Fulfillment in a Traditional School in Porto Alegre]. Dissertação (Mestrado em Educação), Faculdade de Educação da) [Dissertation (Master in Education), Faculty of Education], Porto Alegre: PUCRS. 
http://repositorio.pucrs.br/dspace/bitstream/10923/2872/1/000434468-Texto\%2BComp leto-\%200.pdf

Dohms, K. P. (2016). Bem-estar Institucional em uma escola da rede Marista. [Institutional Well-Being in a Marist School]. Tese (Doutorado em Educação), Faculdade de Educação da PUCRS [Thesis (Doctorate in Education), Faculty of Education], Porto Alegre: PUCRS.

http://repositorio.pucrs.br/dspace/handle/10923/7992

Esteve, J. M. (1999). O mal-estar docente. A sala de aula e a saúde dos professores [Teacher Malaise. The Classroom and the Health of Teachers]. Bauru: Edusc.

Esteve, J. M. (2004). A terceira revolução educacional. A educação na sociedade do conhecimento [The Third Educational Revolution. Education in the Knowledge Society]. São Paulo: Moderna.

Esteve, J. M. (2005). Bem-estar e saúde docente. Revista PRELAC. Educação para todos. Publicado pelo Escritório Regional de Educação da UNESCO para a América Latina e o Caribe. OREALC/UNESCO Santiago. Impresso no Chile por AMF Imprenta. Santiago, Chile: ano I, n. 1, 116-133.

Freud, S. (1974). O mal-estar na civilização [The Malaise in Civilization]. Rio de Janeiro: Imago.

Grotberg, E. (1995). A Guide to Promoting Resilience in Children: Strengthening the Human Spirit. Early Childhood Development: Practice and Reflections, v. 8. The Hague-NO: Bernard Van Leer Foundation.

Hernández, P. (2002). Los moldes de la mente [The Molds of the Mind]. La Laguna: Tafor.

Hué García, C. (2008). Bienestar docente y pensamiento emocional [Teaching Well-Being and Emotional Thinking]. Madrid: Wolters Kluwer Educación.

Imbernón, F. (2000). Formação docente e profissional: Formar-se para a mudança e a incerteza [Teacher and Professional Formation: Training for Change and Uncertainty] (8th Ed.). São Paulo: Cortez.

Jesus, S. N. de, \& Rezende, M. (2009). Saúde e Bem-estar [Health and Well-Being]. In J. Cruz, S. de Jesus, \& C. Nunes, (Coord.), Bem-Estar e Qualidade de Vida: Contributos da Psicologia da Saúde [Well-Being and Quality of Life: Contributions of Health Psychology]. Lisbon-PT: Textiverso.

Jesus, S. N. de. (2001). Pistas para o bem-estar dos professores [Tracks for the Well-Being of Teachers] (No. 43, pp. 123-132). Porto Alegre: Educação.

Jesus, S. N. de. (2004). Desmotivação e crise de identidade na profissão docente [Demotivation and Identity Crisis in the Teaching Profession] (Vol., 7, No. 2, pp. 192-202). Florianópolis: Katálysis.

Jesus, S. N. de. (2007). Professor sem stress [Teacher without Stress]. Porto Alegre: Mediação Editora.

Jung, C. G. (1972). El yo y el inconsciente. Barcelona: Luis Miracle.

Kelchtermans, G. O. (2009). Comprometimento profissional para além do contrato: Autocompreensão, vulnerabilidade e reflexão dos professores [The Professional Commitment beyond the Contract: Self-Understanding, Vulnerability and Reflection of Teachers]. In M. A. Flores, \& A. M. V. Simon, (Org.), Aprendizagens e desenvolvimento profissional de professores: Contextos e perspectivas [Learning and Professional Development of Teachers: Contexts and Perspectives]. Almada, PT: Pedago.

Mandra, R. (1980). Le mosaïque éducation. Paris: Edilig.

Marchesi, A. (2008). O bem-estar de professores: competências, emoções e valores [The Welfare of Teachers: Skills, Emotions and Values]. Porto Alegre: Artmed. 
Maristas. (2015a). Escritos de Marcelino [Writings of Marcellin]. http://www.champagnat.org/510.php

Maristas. (2015b). Missão, Visão e Valores que inspiram a atuação Marista [Mission, Vision and Values that Inspire Marist action]. http://maristas.org.br/institucional/missao-visao-e-valores

Masschelein, J., \& Simons, M. (2002). Na Adequate Education for the Globalized World? A Note on the Immunization of Being-Together. Journal of Philosophy of Education,. $36,565-584$.

Maturana, H. (1998). Emoções e linguagem na educação e na política [Emotions and Language in Education and Politics]. Belo Horizonte: Editora UFMG.

Mendes, A. R. (2011). Saúde docente: uma realidade detectada em direção ao bem-estar e a realização profissional [Teaching Health: A Reality Detected toward Well-Being and Professional Achievement]. Dissertação (Mestrado em Educação), Faculdade de Educação [Dissertation (Master in Education), Faculty of Education], Porto Alegre: PUCRS.

http://repositorio.pucrs.br/dspace/bitstream/10923/2721/1/000437482-Texto\%2BComp leto-0.pdf

Menezes, I. V., \& Gazzotti, A. A. (2006). Suporte afetivo e o sofrimento psíquico em burnout [Affective Support and Psychic Suffering in Burnout]. In W. Codo (Coord.), Educação, carinho e trabalho [Education, Care and Work] (pp. 35-48). Petrópolis: Vozes.

Milstein, M. M., Golaszewski, T. J., \& Duquete, R. D. (1984). Organizationally Based Stress: What Bothers Teachers. Journal of Educational Research, 77, 293-297. https://doi.org/10.1080/00220671.1984.10885543

Morin, E. (2009). A cabeça bem-feita: repensar a reforma, reformar o pensamento [The Well-Done Head: Rethinking Reform, Reforming Thinking]. Rio de Janeiro: Bertrand Brasi.

Mosquera, J. J. M. (1978). Professor como pessoa [The Teacher as a Person]. Porto Alegre: Sulina.

Mosquera, J. J. M., \& Stobäus, C. D. (2006a). Afetividade: A manifestação de sentimentos na educação [Affectivity: The Manifestation of Feelings in Education] (No. 1, pp. 123 133). Porto Alegre: Educação.

Mosquera, J. J. M., \& Stobäus, C. D. (2006b). Auto-imagem, Auto-estima e Autorealização: qualidade de vida na universidade [Self-Image, Self-Esteem and SelfRealization: Quality of Life in the University] (Vol. 7, No. 1, pp. 83-88). Saúde e Doenças: Psicologia.

Mosquera, J. J. M., \& Stobäus, C. D. (2008). O Professor, personalidade saudável e relações interpessoais: por uma educação para a afetividade [The Teacher, Healthy Personality and Interpersonal Relationships: By an Education for Affectivity]. In D. Enricone (Ed.), Ser professor [Be a Teacher]. Porto Alegre: EdiPUCRS.

Mosquera, J. J. M., \& Stobäus, C. D. (2010). Pessoas, Trabalho e Motivações [People, Work and Motivations]. In B. S. dos Santos, \& A. B. Carreño (Eds.), A motivação em diferentes cenários [The Motivation in Different Scenarios]. Porto Alegre: EdiPUCRS.

Mosquera, J. J. M., \& Stobäus, C. D. (2011a). O envelhecimento saudável: Educação, Saúde e Psicologia positiva [Healthy Aging: Education, Health and Positive Psychology]. II Congresso Luso-Brasileiro de Psicologia da Saúde e I Congresso IberoAmericano de Psicologia da Saúde, 2011, São Bernardo do Campo. Transformações socioculturais e promoção de saúde. Anais... São Bernardo do Campo: Universidade Metodista de São Paulo, p. 1-11.

Mosquera, J. J. M., \& Stobäus, C. D. (2011b). A Psicologia Positiva e suas implicaçôes para 
a psicopedagogia: um debate em aberto [Positive Psychology and Its Implications for Psychopedagogy: An Open Debate]. In: III Seminário Internacional Pessoa Adulta, Saúde e Educação. Espaços Psicopedagógicos em Diferentes Cenários [International Seminar on Adulthood, Health and Education, Psychopedagogical Spaces in Different Scenarios]. Anais ... Porto Alegre: Pontifícia Universidade Católica do Rio Grande do Sul, 2011b, p. 1-13.

Mosquera, J. J. M., \& Stobäus, C. D. (2012). Psicologia Positiva e calendário emocional: construção saudável de si [Positive Psychology and Emotional Timing: Healthy Self-Building] (pp. 857-873). III Congresso Brasileiro de Psicologia da Saúde e IV Jornada Científica do Programa de Pós-Graduação em Psicologia Brazilian [Congress of Health Psychology and IV Scientific Conference of the Graduate Program in Psychology] da Universidade Federal de Santa Maria, 2012, Santa Maria. Trabalhos integrados em Saúde: Desafios e Perspectivas. Anais... Santa Maria: Universidade Federal de Santa Maria.

Mosquera, J. J. M., Stobäus, C. D., \& Santos, B. S. dos. (2007). Processos motivacionais em contextos educativos [Motivational Processes in Educational Contexts] (pp. 297-306). Porto Alegre: Educação.

Organización Mundial de la Salud, OMS. (2012). Temas de salud: Salud Mental [World Health Organization, WHO. Health Topics: Mental Health]. http://www.who.int/topics/mental_health/en/

Portal, L. L. F. (2008). O professor e o despertar de sua espiritualidade [The Teacher and the Awakening of His Spirituality]. In D. Enricone et al. (Org.), Ser professor [Be a Teacher]. Porto Alegre: EdiPUCRS.

Rogers, C. R. (1997). Tornar-se pessoa [Becoming a Person]. São Paulo: Martins Fontes.

Ryan, R., \& Deci, E. (2002). Overview of Self-Determination Theory: An Organismic Dialectial Perspective. In E. Deci, \& R. Ryan (Eds.), Handbook of Self-Determination Research. New York: The University of Rochester Press.

Santos, B. S. dos, \& Carreño, A. B. (2010). A motivação em Diferentes Cenários [The Motivation in Different Scenarios]. Porto Alegre: EdiPUCRS.

Sattler, M. (2011). Formação (Bildung): entre o sagrado e o profane (vol. 34, pp. 49-55). Porto Alegre: Educação.

Seligman, M. E. P. (1998). Building Human Strength: Psychology's Forgotten Mission. APA Monitor, 29, 2.

Seligman, M. E. P., \& Csikszentmihalyi, M. (2000). Positive Psychology. American Psychologist, 55, 5-14.

Snyder, C. R., \& Lopez, S. J. (2009). Psicologia Positiva: Uma abordagem científica e prática das qualidades humanas [Positive Psychology: A Scientific and Practical Approach to Human Qualities]. Porto Alegre: Artmed.

Soratto, L., \& Olivier-Heckler, C. (1999). Os trabalhadores e seu trabalho [The Workers and Their Work]. In W. Codo (Org.), Educação: Carinho e trabalho [Education: Caring and Work] (pp. 89-110). Petrópolis: Vozes.

Soratto, L., \& Pinto, R. (1999). Burnout e carga mental no trabalho [Burnout and Mental Load at Work]. In W. Codo (Org.), Educação: carinho e trabalho [Education: Caring and Work] (pp. 282-292). Petrópolis: Vozes.

Sousa, C. (2006). Educação e resiliência [Education for Resilience]. Tavira-PT: Município de Tavira.

Timm, E. Z. (2010). Refletindo sobre a motivação docente: sou professor, porque isso me faz bem [Reflecting on Teacher Motivation: I Am a Teacher Because It Makes Me Feel Good]. In B. S. Dos Santos, \& A. B. Carreño (Eds.), A motivação em diferentes cenário 
[The Motivation in Different Scenarios]. Porto Alegre: EdiPUCRS.

União Marista do Brasil [Marist Union of Brazil]. (2010). Projeto Educativo do Brasil Marista. Nosso jeito de conceber a Educação Básica [Educational Project of Marist Brazil. Our Way of Designing Basic Education]. Brasília: UMBRASIL.

Waichman, P. (2002). Tempo livre e Recreação: Um desafio pedagógico [Free Time and Recreation: A Pedagogical Challenge]. Campinas: Papirus.

Submit or recommend next manuscript to SCIRP and we will provide best service for you:

Accepting pre-submission inquiries through Email, Facebook, LinkedIn, Twitter, etc. A wide selection of journals (inclusive of 9 subjects, more than 200 journals) Providing 24-hour high-quality service User-friendly online submission system Fair and swift peer-review system Efficient typesetting and proofreading procedure Display of the result of downloads and visits, as well as the number of cited articles Maximum dissemination of your research work

Submit your manuscript at: http://papersubmission.scirp.org/ Or contact ce@scirp.org 